\title{
Response of soil respiration under different mycorrhizal strategies to precipitation and temperature
}

\author{
Z. Shi ${ }^{1,2^{*}}$, F. Wang ${ }^{1}$ and Y. Liu ${ }^{1}$ \\ ${ }^{1}$ Agricultural College, Henan University of Science and Technology, Tianjin Road 70, Luoyang 471003, Henan \\ Province, People's Republic of China. ${ }^{2}$ Laboratory For Earth Surface Processes, Ministry of Education, Peking \\ University, Beijing 100094, People's Republic of China *Corresponding author: shizy1116@126.com
}

\begin{abstract}
The symbiotic associations between plant roots and mycorrhizal fungi are almost ubiquitous. These interactions can produce a large amount of soil respiration $\left(\mathrm{R}_{\mathrm{s}}\right)$ and respond strongly to such climatic changes as temperature and precipitation. The objective of the present study was to explore how interannual variations in environmental factors (i.e., temperature and precipitation) and biotic factors (leaf area index, LAI) influence soil respiration and its temperature sensitivity (apparent $Q_{10}$ ) in global forest ecosystems that are classified by the mycorrhizae of the dominant plants. Based on a global forest database, the mycorrhizal strategy of tree species over 200 site-years was determined. The $\mathrm{R}_{\mathrm{s}}$ on the global scale was largely controlled by temperature. When the mycorrhizal strategy was considered, the responses of the $\mathrm{R}_{\mathrm{s}}$ to the mean annual temperature (MAT), mean annual precipitation (MAP) and LAI were highly variable among different mycorrhizal strategies. For example, the $\mathrm{R}_{\mathrm{s}}$ was explained mainly by the LAI for arbuscular mycorrhizal (AM) and $\mathrm{AM}+$ ectomycorrhizal (ECM) types and by the MAT for ECM and ECM+EEM (ectendomycorrhizal) $+\mathrm{NM}$ (non-mycorrhizal) types. The apparent $Q_{10}$ of the $\mathrm{R}_{\mathrm{s}}$ was not significantly different. This study was the first to evaluate the influence of different mycorrhizal strategies on forest $R_{s}$ on the global scale. The mycorrhizal strategy plays an important role in the interpretation of the current soil respiration data.
\end{abstract}

Keywords: Soil respiration, mycorrhizal strategy, temperature, precipitation, leaf area index. 


\section{Introduction}

After photosynthesis, soil respiration $\left(\mathrm{R}_{\mathrm{s}}\right)$ accounts for the second largest carbon (C) flux in most ecosystems: 60-90\% of the total ecosystem respiration (Longdoz et al., 2000). Forest soil respiration arising from root activity and the associated mycorrhizal fungi (Hanson et al., 2000; Subke et al., 2006) is the primary pathway by which plant-fixed carbon dioxide $\left(\mathrm{CO}_{2}\right)$ is released back into the atmosphere (Gaumont-Guay et al., 2009). Because of the large annual carbon fluxes between forest ecosystems and the atmosphere (Bonan, 2008), these ecosystems are likely to influence the global carbon balance in response to the projected climate change (Savage et al., 2008). The realization that soils are a possible source of atmospheric $\mathrm{CO}_{2}$, together with the continuous increase in atmospheric $\mathrm{CO}_{2}$ concentrations, has lead to enormous interest from numerous ecologists (Raich et al., 2002; Gaumont-Guay et al., 2009). R, as the most uncertain component of many climate change models (Jones et al., 2003), is influenced by many factors, e.g., the temperature, precipitation and leaf area index (LAI) (Reichstein et al., 2003), but the effect of biological variables on respiration and the interaction of biotic and abiotic factors remain poorly understood on the global scale.

Mycorrhizal fungi play crucial roles in the regulation of terrestrial $\mathrm{CO}_{2}$ fluxes (Zhu and Miller, 2003); these fungi are obligate symbionts that form mutualistic relationships with plant roots known as a mycorrhiza. In terrestrial ecosystems, symbiotic associations between plant roots and mycorrhizal fungi are nearly ubiquitous, with $90 \%$ of all plant species forming mycorrhizae (Smith and Read, 2008). Indeed, the prevalence of these relationships has led to the assertion that "the majority of plants, strictly speaking, do not have roots; they have mycorrhizae" (http:// www.kent.ac.uk/bio/beg/). Mycorrhizal fungi receive carbon from their host plants (Hobbie, 2006) in exchange for nutrient transfer to the roots, which benefits plant growth. Previous studies have demonstrated the roles of mycorrhizae in soil respiration (Högberg et al., 2001; Langley et al., 2005; Heinemeyer et al., 2007; Moyano et al., 2008; Vargas and Allen, 2008). Although respiratory $\mathrm{CO}_{2}$ release from mycorrhizae might be greater than from non-mycorrhizal roots (Valentine and Kleinert, 2007; Nottingham et al., 2010), the mycorrhizal status is rarely considered when examining the scaling relationships between the $\mathrm{R}_{\mathrm{s}}$ and its impact factors. The global predominance of mycorrhizal associations and their key role in soil $\mathrm{C}$ input means that the mycorrhizal influence on the $\mathrm{R}_{\mathrm{s}}$ represents an important deficiency in our knowledge.

Previous studies have focused on how environmental and biological factors i.e., temperature, precipitation and LAI influence soil respiration (Reichstein et al, 2003; Bond-Lamberty and Thomson, 2010; Wang et al., 2010) at large, even global scales. These studies have focused on the categorical classifications by forest type (e.g., evergreen forests and deciduous forests; conifer forests and deciduous forests) (Luyssaert et al, 2007) or biome (e.g., boreal, temperature and tropical) (Bond-Lamberty and Thomson, 2010) but have ignored the potential role of the belowground interactions and feedbacks that may influence the $\mathrm{R}_{\mathrm{s}}$. Consequently, it is unclear whether environmental factors influence $\mathrm{R}_{\mathrm{s}}$ differently in vegetation types dominated by different mycorrhizal plants across large geographical distances. The failure to examine properly the role of colonization in determining root respiration means that the current interpretations of the root and soil respiration data might be flawed.

In this study, we use a recently compiled global forest C-flux database (Luyssaert et al., 2007) to investigate the dependency of the forest annual $\mathrm{R}_{\mathrm{s}}$ on the temperature, precipitation and LAI. With this information, we classified the study sites by the mycorrhizal strategy of their dominant plants. We expect that classifying those sites according to their dominant mycorrhizal strategy will provide a new insight into how to incorporate other belowground factors in global climate research. 
The goal of this study was to improve the understanding of the functional role of mycorrhizal associations in soil respiration. We hypothesize that the temperature, precipitation and LAI may differentially regulate $\mathrm{R}_{\mathrm{s}}$ in different mycorrhizal strategy-dominated systems. We expect that patterns may emerge across large geographical distances in forests dominated by different mycorrhizal strategies.

\section{Materials and Methods}

\section{Data sets}

This work is based on a global forest C-flux database developed by Luyssaert et al. (2007), which included forest carbon-flux data of tree species, R, LAI, mean annual temperature (MAT) and mean annual precipitation (MAP). The mycorrhizal strategy of each species was ascertained and classified according to published literature (e.g., Smith and Read, 2008). When tree species were reported to associate with more than one mycorrhizal type, they were classified as an A mycorrhizal type $+B$ mycorrhizal type $+C$ mycorrhizal type $+D$ mycorrhizal type combination. For example, a tree was classified as an arbuscular mycorrhiza (AM) + ectomycorrhiza (ECM) combination when it was reported to associate with both AM and ECM mycorrhizal fungi. The mycorrhizal strategy of 257 site-year tree species was cleared, including the following 7 mycorrhizal strategies: (1) AM (45 ); (2) AM+ECM (62); (3) AM+ECM+EEM (ectendomycorrhiza) (3); (4) AM+ECM+EEM+NM (non-mycorrhiza) (4); (5) ECM (102); (6) ECM+EEM (23); and (7) $\mathrm{ECM}+\mathrm{EEM}+\mathrm{NM}$ (18). Both AM+ECM+EEM and $\mathrm{AM}+\mathrm{ECM}+\mathrm{EEM}+\mathrm{NM}$ types were removed because of insufficient data. We then matched the mycorrhizal type with the $\mathrm{R}_{\mathrm{s}}$. In total, five mycorrhizal strategies, including (1) AM (41), (2) AM+ECM (44), (3) ECM (86), (4) $\mathrm{ECM}+\mathrm{EEM}$ (12), and (5) ECM+EEM+NM (17), were used in this study because of the default of $\mathrm{R}_{\mathrm{s}}$ data. Fur- thermore, the relationship between the LAI and $\mathrm{R}_{\mathrm{s}}$ was analyzed under different mycorrhizal strategies.

\section{Data analysis}

At the global scale, the $\mathrm{R}_{\mathrm{e}}$ is linearly correlated with the MAT and MAP (Schimel et al., 2001; Raich et al., 2002; Wang et al., 2010). To test whether the response of the $\mathrm{R}_{\mathrm{s}}$ to the MAT varied depending on different mycorrhizal strategies and whether they presented a linear correlation, we analyzed their relationship using the linear and exponential regression of the SPSS software package version 13.0 (SPSS, Chicago, IL). We also analyzed the data using linear regression to characterize the responses of the $\mathrm{R}_{\mathrm{s}}$ to the MAP and LAI under different mycorrhizal strategies.

To test for differences of the temperature sensitivity (apparent $Q_{10}$ ) of the $\mathrm{R}_{\mathrm{s}}$ under mycorrhizal strategies, the apparent $Q_{10}$ of all site-years and each mycorrhizal type were calculated by the MAT. The apparent $Q_{10}$ values were subjected to a Chi-Square Test under the different mycorrhizal-strategy forests to examine whether the variability depended on the mycorrhizal strategies of the tree species.

\section{Results}

When all of the mycorrhizal-type forests were considered, the $\mathrm{R}_{\mathrm{s}}$ increased significantly with increasing MAT, with a linear regression of $\mathrm{R}_{1}^{2}=0.2421(p<0.001)$ and an exponential regression of $\mathrm{R}_{\mathrm{e}}{ }^{2}=0.2562(p<0.001)$ (Figure $2)$. The exponential model simulated the relationship between MAT and $\mathrm{R}_{\mathrm{s}}$ better than the linear model. Regarding the different mycorrhizal strategy-dominated forests, the MAT markedly influenced the $\mathrm{R}_{\mathrm{s}}$ in the forests associated with $\mathrm{AM}+\mathrm{ECM}, \mathrm{ECM}$, and $\mathrm{ECM}+\mathrm{EEM}+\mathrm{NM}$ mycorrhizal types (Figure 2). The effect of the MAT explained the variation of $42 \%, 34 \%$ and $39 \%$ of the $\mathrm{R}_{\mathrm{s}}$ in the $\mathrm{AM}+\mathrm{ECM}, \mathrm{ECM}$, and $\mathrm{ECM}+\mathrm{EEM}+\mathrm{NM}$ forests, 
whereas no significant correlation between the MAT and $\mathrm{R}_{\mathrm{s}}$ was observed in the AM- and ECM+EEM+NM-dominated forests. In contrast, the linear model was more suit-
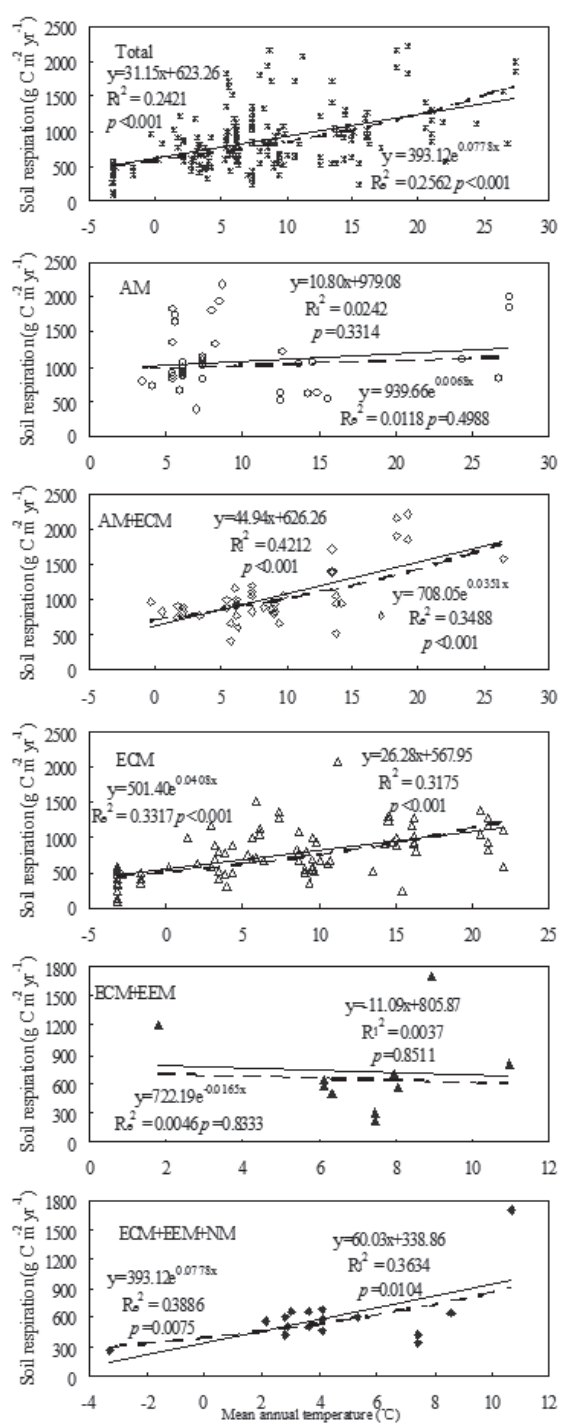

Figure 1. Relationship between soil respiration and mean annual temperature under different mycorrhizal strategy-dominated forests. The real and broken lines indicate linear and exponential regression, respectively. able for AM and AM+ECM than the exponential model. Conversely, the exponential model better explained the $\mathrm{ECM}, \mathrm{ECM}+\mathrm{EEM}$ and ECM+EEM+NM types.
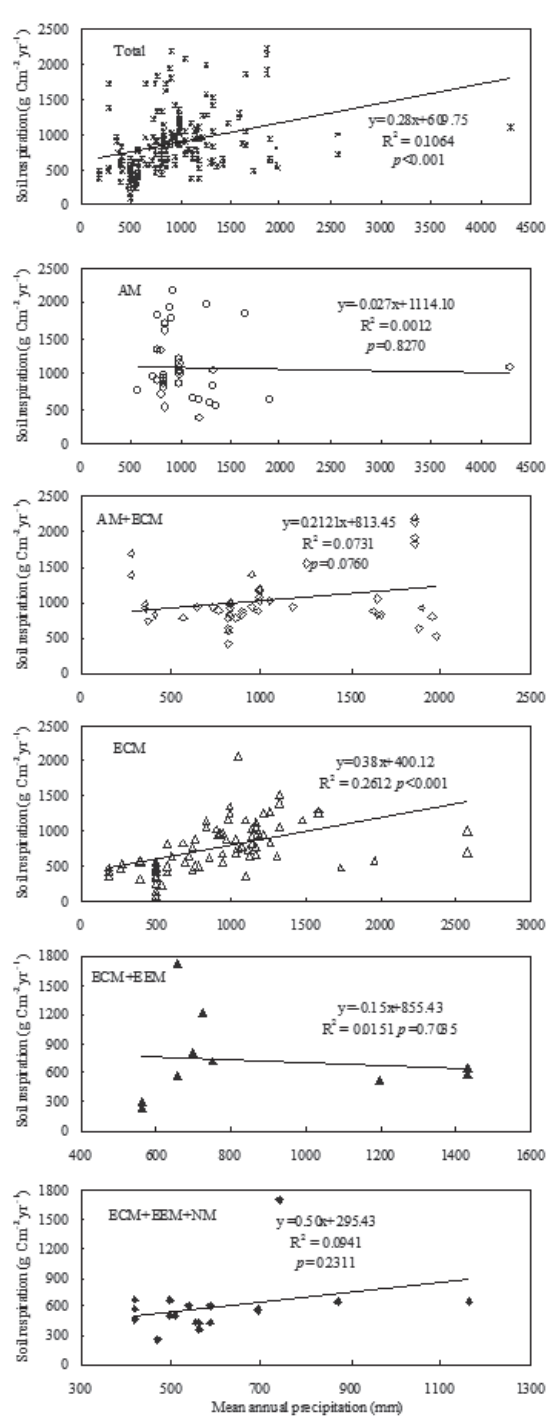

Figure 2. Relationship between soil respiration and mean annual precipitation under different mycorrhizal strategy-dominated forests. 
Similar to the MAT, the $\mathrm{R}_{\mathrm{s}}$ responded linearly to the MAP for all of the site-years, although it only explained $11 \%(p<0.001)$ of the variation of $\mathrm{R}_{\mathrm{s}}$ (Figure 3). When different mycorrhizal-type forests were considered, the effect of the MAP on the $\mathrm{R}_{\mathrm{s}}$ was only significant in the $\operatorname{ECM}\left(\mathrm{R}^{2}=0.2612, p<0.001\right)$ forest. In contrast, when only the ECM type affected by both the MAT and MAP was considered, the effect of the MAT explained $8 \%$ more of the variation in the $R_{s}$ than the effect of the MAP. There were no significant linear relationships between the MAP and $R_{s}$ in the other four mycorrhizal-type forests.
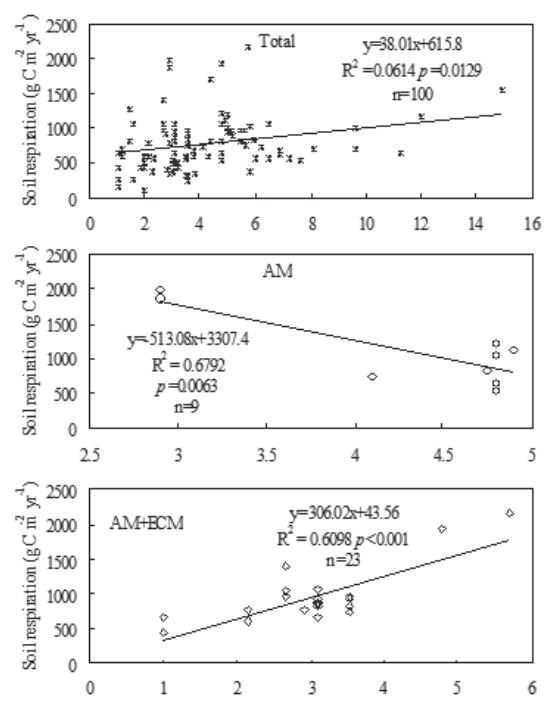

Although the $\mathrm{R}_{\mathrm{s}}$ increased significantly with an enhancement of the LAI, the $\mathrm{R}_{\mathrm{s}}$ presented a weak correlation with the LAI $\left(\mathrm{R}^{2}=0.0614, p=0.0129\right)$ (Figure 3). The effect of the LAI on the $\mathrm{R}_{\mathrm{s}}$ was strong in the AM, AM+ECM and ECM forest types, explaining $68 \%, 61 \%$, and $23 \%$ of the $\mathrm{R}_{\mathrm{s}}$ variations, respectively. Unlike the AM+ECM and ECM forests, a significant negative effect of the LAI on the $\mathrm{R}_{\mathrm{s}}$ $\left(\mathrm{R}^{2}=0.6792, p<0.001\right)$ was found for the AM-dominated forest (Figure 3).
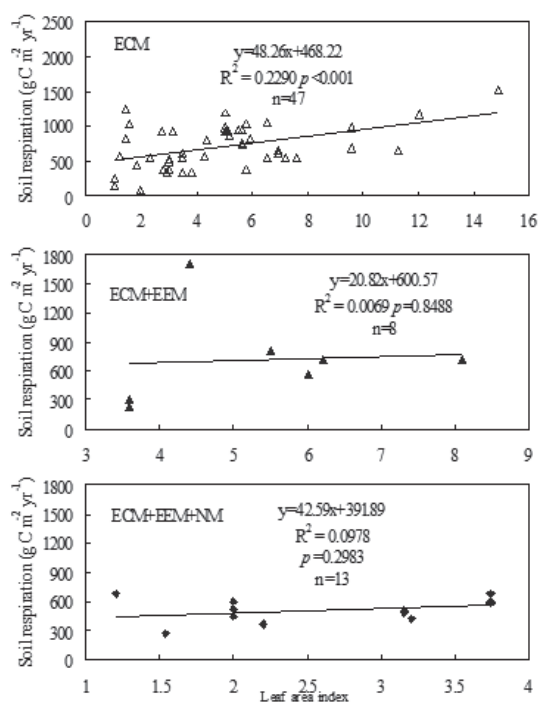

Figure 3. Relationship between soil respiration and leaf area index under different mycorrhizal strategydominated forests. 
The apparent $Q_{10}$ of the $\mathrm{R}_{\mathrm{s}}$ was 1.47 when all of the mycorrhizal types were considered (Figure 4). The apparent $Q_{10}$ changed from 0.85 to 2.18 depending on the different mycorrhizal-dominated forests, whereas no significant difference was observed among them $\left(\chi^{2}=0.8571, p=0.9306\right)$.

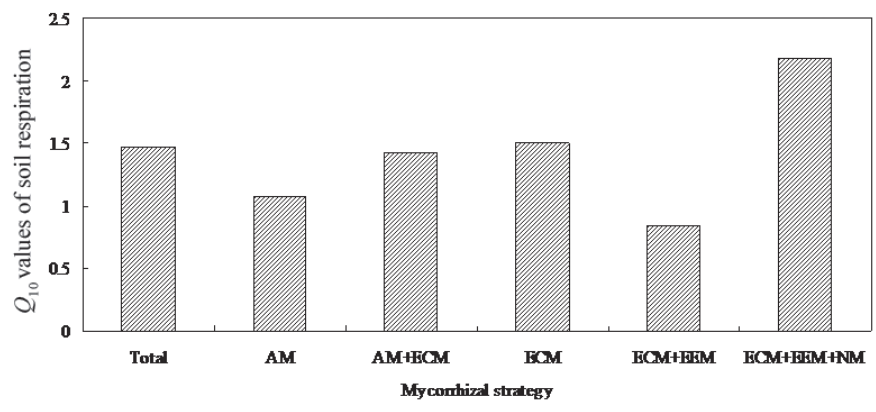

Figure 4. $Q_{10}$ values of soil respiration under different mycorrhizal strategy-dominated forests. $\chi^{2}=0.8571, p=0.9306, \mathrm{df}=4$

\section{Discussion}

The novel aspect of this work is that we used a global $\mathrm{R}_{\mathrm{s}}$ data set and explored the interannual relationships between the $\mathrm{R}_{\mathrm{s}}$ and the MAT, MAP and LAI after classifying the forests according to their mycorrhizal strategy. Previous studies have compared the $\mathrm{R}_{\mathrm{s}}$ of mycorrhizal or non-mycorrhizal strategies and their response to temperature (Högberg et al., 2001; Langley et al., 2005; Heinemeyer et al., 2007; Valentine and Kleinert, 2007), but, to our knowledge, this is the first study to compare the $\mathrm{R}_{\mathrm{s}}$ with the MAT, MAP and LAI among global forest ecosystems based on their mycorrhizal strategies. The present study used a larger research scale and is aimed at increasing our understanding of the effects of mycorrhizal strategies on the $\mathrm{R}_{\mathrm{s}}$ at the global scale. Therefore, we expected to gain a better comprehension of the role of mycorrhizae in $\mathrm{R}_{\mathrm{s}}$ for correctly interpreting the current root and soil respiration data (Hughes et al., 2008).

Our results indicate that, at the global scale, the $\mathrm{R}_{\mathrm{s}}$ presents a significant correlation with the MAT, MAP and LAI, a finding that was consistent with previous evidence (Reichstein et al., 2003; Luyssaert et al., 2007; Bond-Lamberty and Thomson, 2010; Wang et al., 2010). However, when the regression relationship between the $\mathrm{R}_{\mathrm{s}}$ and MAT included AM mycorrhizal forests (all site-years, AM, AM+ECM), the exponential relationship was more suitable than a linear one, which contradicted previous many conclusions (Schimel et al., 2001; Raich et al., 2002; Wang et al., 2010). The reasons for this result require further investigation through the collection of additional data because no exponential model was employed in the above studies. The contribution of the MAT was larger than the MAP on the interannual variability of the $\mathrm{R}_{\mathrm{s}}$, with the exception of for the ECM+EEM mycorrhizal-dominated forest. This finding conflicted with the previous conclusion that the MAP had a larger contribution than the MAT on $\mathrm{R}_{\mathrm{s}}$. However, the interpreter ratio (26\%) of the MAT was similar to the finding (26\%) of Wang et al (2010) for a global forest ecosystem; in contrast, our finding was lower than that (42\%) of Bond-Lamberty and Thomson (2010) for a global forest ecosystem and 
the conclusion (76\%) reported by (Raich et al., 2002) at a global scale. These discrepancies may be due to the difference of the methods employed during the data measurements and data analyses because diverse measurement methods cause variations of the $\mathrm{R}_{\mathrm{s}}$ (Wayson et al., 2006) and the previous discrepancy also presented among many previous studies (Raich et al., 2002; Reichstein et al., 2003; Bond-Lamberty and Thomson, 2010; Wang et al., 2010). In addition, the mycorrhizal status was considered as the first selection level in this study. As a result, we removed those data for which the mycorrhizal status of the corresponding tree species was never reported, which also may account for the differences. Our finding showed that there is a significant positive correlation between the $\mathrm{R}_{\mathrm{s}}$ and LAI when all of the site-years were taken into account, supporting the conclusion of Reichstein et al. (2003). However, our interpretation ratio of the LAI to the $\mathrm{R}_{\mathrm{s}}(6 \%)$ was dissimilar the finding (69\%) of Reichstein et al. (2003). This distinction may be due to the difference of region studied; the study of Reichstein et al. was conducted in 17 different forest and shrubland sites in Europe and North America. In addition, the mycorrhizal strategy most likely exerted an important influence. The LAI explained different variation of the $\mathrm{R}_{\mathrm{s}}$ with changes of the mycorrhizal strategies. Furthermore, Reichstein et al. (2003) presented significant negative relationship $(\mathrm{r}=-0.8241)$ with the AM-dominated forest.

The $Q_{10}$ (1.47) was similar to the finding (1.5) of Bond-Lamberty and Thomson (2010) in which the $Q_{10}$ was calculated by air temperature in the two studies. When the $Q_{10}$ was considered under different mycorrhizal strategies, we found that, although the $Q_{10}$ fluctuated according to the mycorrhizal strategy, the variation was not significant among the different mycorrhizal strategies. This finding confirmed the conclusions of the majority of studies (Langley et al., 2005; Atkin et al., 2009). However, Koch et al. (2007) showed that the $Q_{10}$ of the $\mathrm{R}_{\mathrm{s}}$ increased $20 \%$ when $P i$ - cea abies was colonized by ECM fungi (Piloderma croceum) compared to non-mycorrhizal plants.

The effects of the mycorrhizal strategy on the ecosystem response to climate change have triggered the interest of ecologists (Zhu and Miller, 2003; Vargas et al., 2010). However, to our knowledge, there was only one report involving mycorrhizal associations and ecosystem respiration at large scales. Moreover, this study only compared different AMs and ECMs on ecosystem $\mathrm{CO}_{2}$ fluxes (Vargas et al., 2010). By reviewing previous literature, we found no report on the response of the forest $\mathrm{R}_{\mathrm{s}}$ to climate changes based on the mycorrhizal strategy at the global scale, although much research have reported the contribution of mycorrhizal fungi to the $\mathrm{R}_{\mathrm{s}}$ under conditions of control pot or field experiments (Högberg et al., 2001; Langley et al., 2005; Hughes et al., 2008). Furthermore, there was no study on the effect of different mycorrhizal types on the $\mathrm{R}_{\mathrm{s}}$ and its $Q_{10}$ and comparing the values between mycorrhizal and non-mycorrhizal species (Högberg et al., 2001; Langley et al., 2005; Hughes et al., 2008). This is the first study to evaluate the $\mathrm{R}_{\mathrm{s}}$ in response to the MAT, MAP, and LAI and the change of the $Q_{10}$ based on multiple mycorrhizal types in global forest ecosystems. Clearly, considerable research effort is required in the future to allow a full quantitative investigation of the function of mycorrhizal associations at a global ecosystem scale.

\section{Acknowledgements}

This study was financially supported by the National Natural Science Foundation of China (Grant 40971150), the Chinese Postdoctoral Science Foundation (20090450004, 20103018), the open fund of Laboratory for Earth Surface Processes, Ministry of Education (2011004), and the Science Foundation Fostering Innovative Ability of Henan University of Science and Technology (2009CZ0006). 


\section{References}

Atkin, O.K., Sherlock, D., Fitter, A.H. 2009. Temperature dependence of respiration in runts colonized by arbuscular mycorrhizal fungi. New Phytologist, 182, 188-199.

Baas, R., van der Werf, A., Lambers, H. 1989. Root respiration and growth in Plantago-major as afected by vesicular-arbuscular myeorrhizal infection. Plant Physiology, 91, 227-232.

Bååth, E., Wallander, H. 2003. Soil and rhizosphere microorganisms have the same $Q_{10}$ for respiration in a model system. Global Change Biology, 9, 1788-1791.

Blakeman, J.P., Mokahel, M.A., Hadley, G. 1976. Effect of Mycorrhizal Infection on Respiration and Activity of Some Oxidase Enzymes of Orchid Protocorms. New Phytologist, 77, 697-704.

Bonan, G.B. 2008. Forests and climate change: forcings, feedbacks, and the climate benefits of forest. Science, 320, 1444-1449.

Bond-Lamberty, B., Thomson, A. 2010. Temperatureassociated increases in the global soil respiration record. Nature, 464, 579-582.

Boone, R.D., Nadelhoffer, K.J., Canary, JD, Kaye, J.P. 1998. Roots exert a strong influence on the temperature sensitivity of soil respiration. Nature, 396, 570-572.

Dixon RK, Solomon, A.M., Brown, S., Houghton, R.A., Trexier, M. C., Wisniewski, J. 1994. Carbon pools and flux of global forest ecosystems. Science, 263, 185-190.

Fitter, A.H., Heinemeyer, A., Staddon, P.L. 2000. The impact of elevated $\mathrm{CO}_{2}$ and global climate change on arbuscular mycorrhizas: a mycocentric approach. New Phytology, 147, 179-187.

Gaumont-Guay, D., Black, T.A., Mccaughey, H. Barr, A.G., Krishnan, P., Jassal, R.S., Nesic, Z. 2009.
Soil $\mathrm{CO}_{2}$ efflux in contrasting boreal deciduous and coniferous stands and its contribution to the ecosystem carbon balance. Global Change Biology, 15, 1302-1319.

Goulden, M.L., Munger, J.W., Fan, S.M., Daube, B.C., Wofsy S.C. 1996. Exchange of carbon dioxide by a deciduous forest: response to interannual climate variability. Science, 271, 1576-1578.

Grace, J., Rayment, M. 2000. Respiration in the balance. Nature, 404, 819-820.

Hanson, P.J., Edwards, N.T., Garten, C.T., Andrews, J.A. 2000. Separating root and soil microbial contributions to soil respiration: a review of methods and observations. Biogeochemistry, 48, 115-146.

Heinemeyer, A., Hartley, I.P., Evans, S.P., De la Fuente, J.A.C., Ineson, P. 2007. Forest soil $\mathrm{CO}_{2}$ flux: uncovering the contribution and environmental responses of ectomycorrhizas. Global Change Biology, 13, 1786-1797.

Hobbie, E.A. 2006. Carbon allocation to ectomycorrhizal fungi correlates with belowground allocation in culture studies. Ecology, 87, 563-569.

Högberg, P., Nordgren, A., Buchmann, N., Taylor, A.F.S., Ekblad, A., Högberg, M.N., Nyberg, G., Ottosson-Löfvenius, M., Read D.J. 2001. Largescale forest girdling shows that current photosynthesis drives soil respiration. Nature, 411, 789792.

Högberg, P., Read, D.J. 2006. Towards a more plant physiological perspective on soil ecology. Trends in Ecology \& Evolution, 21, 548-554.

Hughes, J.K., Hodge, A., Fitter, A.H., Atkin, O.K. 2008. Mycorrhizal respiration: implications for global scaling relationships. Trends in plant science, 13, 583-588.

Johnson, D., Leake, J.R., Ostle, N., Ineson, P., Read, D.J. 2002. In situ ${ }^{13} \mathrm{CO}_{2}$ pulse-labelling of upland grassland demonstrates a rapid pathway of carbon 
flux from arbuscular mycorrhizal mycelia to the soil. New Phytologist, 153, 327-334.

Jones, C.D., Cox, P., Huntingford, C. 2003. Uncertainty in climate-carbon-cycle projections associated with the sensitivity of soil respiration. Tellus, $55,642-648$.

Langley, J.A., Johnson, N.C., Koch, G.W. 2005. Mycorrhizal status influences the rate but not the temperature sensitivity of soil respiration. Plant and Soil, 277, 335-344.

Longdoz, B., Yernaux, M., Aubinet, M. 2000. Soil $\mathrm{CO}_{2}$ efflux measurements in a mixed forest: impact of chamber distances, spatial variability and seasonal evolution. Global Change Biology, 6, 907-917.

Luyssaert, S., Inglima, I., Jung, M., Richardson, A.D., Reichstein, M., Papale, D., Piao, S.L., Shulze, E.D., Wingate, L., Matteucci, G., Aragao, L., Aubinet, M., Beer, C., Bernhofer, C., Black, K.G., Bonal, D., Bonnefond, J.M., Chambers, J., Ciais, P., Cook, B., Davis, K.J., Dolman, A.J., Gielen, B., Goulden, M., Grace, J., Granier, A., Grelle, A., Griffis, T., Grunwald, T., Guidolotti, G., Hanson, P.J., Harding, R., Hollinger, D.Y., Hutyra, L.R., Kolari, P., Kruijt, B., Kutsch, W.; Lagergren, F., Laurila, T., Law, B.E., Le Maire, G., Lindroth, A., Loustau, D., Malhi, Y., Mateus, J., Migliavacca, M., Misson, L., Montagnani, L., Moncrieff, J., Moors, E., Munger, J.W., Nikinmaa, E., Ollinger, S.V., Pita, G., Rebmann, C., Roupsard, O., Saigusa, N., Sanz, M.J., Seufert, G., Sierra, C., Smith, M.L., Tang, J., Valentini, R., Vesala, T., Janssens, I.A.. et al (2007) $\mathrm{CO}_{2}$ balance of boreal, temperate, and tropical forests derived from a global data base.Global Change Biology, 13, 2509-2537.

Luyssaert S, Schulze ED, Börner A., Knohl A., Hessenmöller D., Law B.E., Ciais P., Grace J. 2008. Old-growth forests as global carbon sinks. Nature, 455, 213-215.
Moyano, F.E., Kutsch, W.L., Rebmann, C. 2008. Soil respiration fluxes in relation to photosynthetic activity in broad-leaf and needle-leaf forest stands. Agricultural and Forest Meteorology, 148, 135143.

Nottingham, A.T., Turner, B.L., Winter, K., van der Heijden, M.G.A., Tanner, E.V.J. 2010. Arbuscular mycorrhizal mycelial respiration in a moist tropical forest. New Phytologist, 186, 957-967.

Raich, J.W., Potter, C.S., Bhagawati, D. 2002. Interannual variability in global soil respiration, 19801994. Global Chang Biology, 8, 800-812.

Raich, J.W., Schlesinger, W.H. 1992. Theglobalcarbondioxide flux in soil respiration and its relationship to vegetation and climate. Tellus, 44, 81-99.

Reichstein M, Rey A, Freibauer A, Tenhunen, J., Valentini, R., Banza, J., Casals, P., Cheng, Y.F., Grunzweig, J.M., Irvine, J., Joffre, R., Law, B. E., Loustau, D., Miglietta, F., Oechel, W., Ourcival, J. M., Pereira, J.S., Peressotti, A., Ponti, F., Qi, Y., Rambal, S., Rayment, M., Romanya, J., Rossi, F., Tedeschi, V., Tirone, G., Xu, M., Yakir, D. 2003. Modeling temporal and large-scale spatial variability of soil respiration from soil water availability, temperature and vegetation productivity indices. Global Biogeochem Cycles, 17, 11041118.

Rygiewicz, P.T., Andersen, C.P. 1994. Mycorrhizae alter quality and quantity of carbon allocated below ground. Nature, 369, 58-60.

Savage, K., Davidson, E.A., Richardson, A.D. 2008. A conceptual and practical approach to data quality and analysis procedures for high-frequency soil respiration measurement. Functional Ecology, 22, 1000-1007.

Schimel DS, House JI, Hibbard KA, Bousquet, P., Ciais, P., Peylin, P. Braswell, B.H., Apps, M.J., Baker, D.,Bondeau, A. Canadell, J., Churkina, G., Cramer, W., Denning, A.S., Field, C.B., Friedlingstein, 
P., Goodale, C., Heimann, M., Houghton, R.A., Melillo, J.M., Moore, B., Murdiyarso, D., Noble, I., Pacala, S.W., Prentice, I.C., Raupach, M.R., Rayner, P.J., Scholes, R.J., Steffen, W.L., Wirth, C. 2001. Recent patterns and mechanisms of carbon exchange by terrestrial ecosystems. Nature, 414, 169-172.

Schuur, E.A.G. 2003. Productivity and global change revisited: the sensitivity of tropical forest growth to precipitation. Ecology, 84, 1165-1170.

Shi, Z.Y., Zhang, X.F., Wang, F.Y. 2010. Influence of mycorrhizal fungi on soil respiration. Ecology a Environmental Sciences, 19, 233-238.

Smith, S.E., Read, D.J. 2008. Mycorrhizal symbiosis. Academic Press, Amsterdam, 787 p.

Snellgrove, R.C., Splittstoesser, W.E., Stribley, D.P., Tinker, P.B. 1982. The distribution of carbon and the demand of the fungal symbiont in leek plants with vesicular-arbuscular mycorrhizas. New Phytologist, 92, 75-87.

Subke, J.A., Inglima, I., Cotrufo, F. 2006. Trends and methodological impacts in soil Trends and methodological impacts in soil $\mathrm{CO}_{2}$ efflux partitioning: a meta-analytical review. Global Change Biology, 12, 921-943.

Treseder, K.K., Allen, M.F. 2000. Mycorrhizal fungi have a potential role in soil carbon storage under elevated $\mathrm{CO}_{2}$ and nitrogen deposition. New Phytology, 147, 189-200.

Valentine, A.J., Kleinert, A. 2007. Respiratory responses of arbuscular mycorrhizal roots to shortterm alleviation of $\mathrm{P}$ deficiency. Mycorrhiza, 17, 137-143
Vargas, R., Allen, M.F. 2008. Environmental controls and the influence of vegetation type, fine roots and rhizomorphs on diel and seasonal variation in soil respiration. New Phytologist, 179, 460-471.

Vargas, R., Baldocchi, D.D., Querejeta, J.I., Curtis, P.S., Hasselquist, N.J., Janssens, I.A., Allen, M.F., Montagnani, L. 2010. Ecosystem $\mathrm{CO}_{2}$ fluxes of arbuscular and ectomycorrhizal dominated vegetation types are differentially influenced by precipitation and temperature. New Phytologist, 185, 226-236.

Wang, B., Qiu, Y.L. 2006. Phylogenetic distribution and evolution of mycorrhizas in land plants. Mycorrhiza, 16, 299-363.

Wang, W, Chen, W.L.,Wang, S.P. 2010. Forest soil respiration and its heterotrophic and autotrophic components: Global patterns and responses to temperature and precipitation . Soil Biology \& Biochemistry, 42, 1236-1244.

Wayson, C.A., Randolph, J.C., Hanson, P.J., Grimmond, C.S.B., Schmid, H.P. 2006. Comparison of soil respiration methods in a mid-latitude deciduous forest. Biogeochemistry, 80, 173-189.

Yim, M.H., Joo, S.J., Nakane, K. 2002. Comparison of field methods for measuring soil respiration: a static alkali absorption method and two dynamic closed chamber methods. Forest Ecology and Management, 170 189-197

Zhu, Y.G., Miller, R.M. 2003. Carbon cycling by arbuscular mycorrhizal fungi in soil-plant systems. Trends in Plant Science, 8, 407-409. 